DOI 10.37882/2223-2982.2021.07.26

\title{
ОСОБЕННОСТИ РЕЧЕВОГО ПОВЕДЕНИЯ ВЕДУЩЕГО ПОПУЛЯРНОГО КИТАЙСКОГО ТОК-ШОУ «ЖИЗНЬ КАК ИСКУССТВО»
}

\section{SPEECH BEHAVIOR PECULIARITIES OF THE HOST OF POPULAR CHINESE TALK SHOW «ART LIFE»}

D. Osipov

Summary: Modern TV is a variety of ideas and genres in the field of telecommunications. Talk shows broadcast on top rated channels are one of the ways the media influence people. The article analyzes peculiarities of speech behavior of the host of the talk show «Art Life». It is a humanistic program imbued with the spirit of philanthropy, through which the Chinese emotional model is spread, and the value system, aesthetic experience and emotional feelings of the Chinese are under the influence.

Keywords: speech behavior, communicative behavior, communicative situation, talk show, Chinese language.

\author{
Осипов Даниил Владимирович \\ К.филол.н., дочент, ФГБОУ ВО «Астраханский \\ государственный университет» \\ d.osipov@asu.edu.ru
}

Аннотация: Современное телевидение - это разнообразие идей, жанров в области телекоммуникаций. Ток-шоу, транслируемые на рейтинговых каналах, это один из способов воздействия СМИ на людей. В статье анализируются особенности речевого поведения ведущего ток-шоу «Жизнь как искусство» — гуманистической программы, проникнутой духом человеколюбия, посредством которой распространяется китайская эмоциональная модель, оказывается влияние на систему ценностей, эстетический опыт и эмоциональные чувства китайцев.

Ключевые слова: речевое поведение, коммуникативное поведение, коммуникативная ситуация, ток-шоу, китайский язык.
$\mathrm{O}$ дним из самых значимых инструментов влияния и формирования общественного мнения считается телевидение. Телевидение, как одно из средств массовой информации, затрагивает те группы населения, которые находятся вне влияния других каналов коммуникации. Телевидение - это способ воздействия на общественное мнение, распространения идей и ценностей, один из эффективных методов, формирующих мировоззрение.

Стоит признать «ценность ток-шоу $\langle\ldots\rangle$, подобные передачи консолидируют различные страты и ячейки общества в единое целое, находя сходство в жизненных позициях, утверждая приемлемые для всех моральные ценности и помогая найти универсальное решение общих проблем. Все участники ток-шоу - от зрителей до экспертов - пытаются смоделировать общую для каждого единичного случая ситуацию, проецируя ее не только на конкретного, сидящего перед нами участника, но и на каждого телезрителя, имеющего к этой проблеме непосредственное отношение» [1, с. 9]. Ток-шоу имеют внутренний сценарий, в котором все участники общаются и влияют друг на друга, и сам процесс представляет собой последовательность лингвистических обменов в ходе коммуникации.

Сама по себе коммуникация - это процесс, нужно осознавать, в какой ситуации, в какое время, и в каком месте она происходит - это характеристики, задающие рамки для речевого поведения участников общения. По словам В.Н. Комиссарова, «смысл любого высказывания будет во многом зависеть от этих факторов, а также от предыдущего опыта коммуникантов, их знаний, чувств и намерений. Высказывания будет иметь различный смысл в зависимости от контекста и ситуации, в которых оно используется. Цель общения и состоит в передаче такого конкретного смысла, понимаемого адресатом» [2, с. 38]. Таким образом, что для нормального восприятия и интерпретации речевой итога немаловажен учет коммуникативной ситуации. Отсюда следует, что выбор языковых средств напрямую зависит от ситуации общения. Способность правильно моделировать коммуникативное поведение в соответствии с ситуацией, а также изменять его в зависимости от изменения ситуации, является важным элементом коммуникативной компетенции человека.

Следует сосредоточится на компонентах общения, которые приобретают определенные свойства в конкретной коммуникативной ситуации ток-шоу. Причины, непосредственно влияющие на особенности этих компонентов, описаны Е.Б. Ростоцкой: «а) наличие нескольких коммуникаторов, среди которых особым статусом обладает модератор, выполняющий в беседе стимулирующую функцию, что включает структурирующий, интерпретативный, прагматический и психологический аспек- 
ты; б) наличие разных групп реципиентов: реципиенты внутреннего круга (коммуникаторы, приглашенные для обсуждения темы телепередачи), реципиенты узкого внешнего круга (публика в студии), реципиенты широкого внешнего круга (телезрители); в) одновременное осуществление как непосредственной коммуникации (между коммуникаторами и между коммуникаторами и отдельными представителями публики в студии), так и опосредованной (между коммуникаторами и телезрителями)» $[3$, с. 10].

Стратегия и тактика речевого поведения - это модель речевой деятельности, после которой участники общения реализуют свои коммуникативные и практические цели и задачи. Речевое поведение - это коммуникативно и социально-психологически обусловленная речевая активность личности, действующая в определенных обстоятельствах и ситуациях общения.

Массовая культура влияет на жизнь людей, их мышление и их ценности, продвигает привычку и способность преодолевать ограничения, учит не слепо следовать за властью, а прививает свободу и независимость мысли. Люди пытаются самоутвердиться, начинают высказывать свое мнение о происходящем и получают право голоса. У них усиливается желание и способность к коммуникативному обмену и участию в общении. Массовая культура занимает важное место в культурной жизни Китая. Под влиянием двух факторов: стремления масс к диалогу и стремления СМИ к свободе - на китайском телевидении появились новые формы: передачи-беседы или так называемым ток-шоу.

Ток-шоу «Жизнь как искусство» было выпущено на канале CCTV 3 в 2000 году. Чжу Цзюнь - его постоянный ведущий, уважаемый человек в Китае. На программу приглашаются люди искусства, большинство из которых - звезды кино, а также певцы, артисты, танцоры, рассказывающие свою личную историю на пути к успеху. По мере развития программы, в студию стали приглашать гостей, которые не только связаны с традиционной китайской культурой и искусством, но и гостей, относящихся к числу этнических китайцев и проживающих за рубежом, а также иностранных деятелей мирового масштаба.

Цель ток-шоу - использование историй героев для распространения китайской эмоциональной модели, оказание влияния на систему ценностей, эстетический опыт и эмоциональные чувства китайцев. Ценность таких программ - это позитивное отношение к миру, позитивный взгляд на вещи, умение «быть хозяином своей судьбы». Особенно важно прочувствовать это зрителю из рассказов своей истории известными людьми. В этом ток-шоу отсутствуют игровые элементы и вводное шоу, программа менее веселая, но более познавательная. Видео с короткой историей о герое показывается в самом начале передачи на большом экране, чтобы познакомить зрителя с героем. Для каждого выпуска приглашается только один герой.

Дж.Г. Скотт следующим образом раскрывает основные характеристики, которыми должен обладать ведущий ток-шоу: «Нужен особый характер $\langle\ldots\rangle$, не такой как у всех темперамент, стремление быть первым и лучшим в своей работе или же самым преданным и самоотверженным; кроме того, ведущие ток-шоу должны уметь развлекать аудиторию, иметь сильный и разработанный маркетинговый план и знать способы его реализации. Их общей чертой является упорный труд, неутомимость, навыки конкурентной борьбы в своей отрасли, и умение быть прекрасными игроками в команде». [4]

Наблюдение за ведущим Чжу Цзюнем выявило следующие основные характеристики, а также стратегии и тактики в его поведении, которые имеют решающее значение для успеха ток-шоу «Жизнь как искусство»:

Чувство сцены и любознательность. Чжу Цзюнь текста. обладает не только сценическим опытом, но и опытом проведения праздничных концертов. Благодаря этому атмосфера искусства царит в студии, где проходит сьемки выпусков. Во время интервью с гостями ток-шоу Чжу Цзюнь может свободно использовать определенные элементы драмы, приглашать неожиданных гостей, переходить от одного предмета разговора к другому, иногда Чжу Цзюнь появляется как артист, выполняя определенный вокальный номер с гостем.

Умение быть хорошим слушателем. Оптимальное общение во время ток-шоу в повышенной эмоциональной атмосфере во многом зависит от способности ведущего психологически управлять беседой с приглашенными гостями, а также от способности слушать выступления своих гостей. Сам Чжу Цзюнь об этом говорил так: 《每个人都可以讲话，每个人都可以提出问题，但并不是 每个人都可以很好地听取对话者的意见。任何能够真正，以深 切的真诚感觉聆听对话者的人，都会收到所有必要的信息。》 («Говорить может каждый, задавать вопросы также может каждый, но далеко не каждый может хорошо выслушать собеседника. Кто в состоянии по-настоящему, с глубоким сердечным неподдельным чувством выслушать собеседника, тот в результате получит всю необходимую информацию».)

Постоянный сторонник традиционной системы ценностей и борец за нее. Структура знаний и система ценностей Чжу Цзюня оказывают решающее влияние на его имидж как ведущего ток-шоу. Он является постоянным сторонником традиционных ценностей, которые, как сказал продюсер ток-шоу Ван Чжэн: 《这是中国老百姓 的传统价值观体系，他们的生活体验》(《Это традиционная система ценностей простого населения Китая, его жиз- 
ненного опыта»). Сам Чжу Цзюнь стремится поддерживать традиционные ценности, такие как любовь, дружба, семья и рассказывать вдохновляющие истории о труде и житейской мудрости. Большинство китайских зрителей придерживаются традиционной системы ценностей.

Активное участие ведущего в создании и подготовке программы. В настоящее время ведущий активно принимает участие в планировании и проведении интервью. Чжу Цзюнь глубоко вовлечен в создание и распространение ток-шоу «Жизнь как искусство». Это помогает ему лучше понять эмоциональную природу гостей и эффективно использовать эти знания для оптимизации общения с ними во время передачи. Сюй Сяофань, специалист по подготовке программы, охарактеризовал участие Чжу Цзюня в создании ток-шоу: 《朱军是脱口秀节目的中流砥柱，他与嘉宾沟通的轻松和 方便背后在于大量的准备工作》 (《Чжу Цзюнь это главная опора ток-шоу, за легкостью и непринужденностью его общения с гостями кроется большая подготовительная работа»). Чжу Цзюнь обычно обобщает сказанное после каждого длинного монолога гостя или обширного вопроса из аудитории и задает ключевой вопрос. Разговор между Чжу Цзюнем и гостями показывает, что ответы не подготовлены заранее и поэтому беседа выглядит естественно и интересно.

Ток-шоу «Жизнь как искусство» - гуманистическая программа, пропитанная духом человечества. Ведущий Чжу Цзюнь обладает такими качествами, как общительность, сердечность, способность понимать людей, харизматичность. Ведущий знает, как привнести искренний эмоциональный настрой в передачу, любит программу которую ведет и искренне уважает гостей. Он с интересом выслушивает их истории, умеет принять проблемы людей близко к сердцу и знает, как влиять на их души, как вызвать гостей на искренний диалог, побуждает зрителей прочувствовать горе и радости, о которых говорит герой в ток-шоу.

Со стороны лексической стилистики в речи ведущего ток-шоу «Жизнь как искусство» следует отметить такую положительную черту, как отсутствие сленга. Еще одна положительная черта речи Чжу Цзюня - отсутствие заимствованных иностранных слов. В последнее время использование в повседневной беседе заимствованных слов стало довольно популярным: «OK», «content», «rap», «cool», «show» и т.д., которые могут быть непонятными для неосведомленного зрителя. Очень часто иностранные слова встречаются в выступлениях телеведущих гонконгских и тайваньских программ, жителей юго-восточного Китая, из-за частых контактов с иностранцами. Речь Чжу Цзюня в этом отношении очень ясна и общедоступна. Третья положительная характеристика - использование диалектной лексики в разговоре с героями. Часто пожилые артисты становятся героями программы, их речь насыщена богатым местным колоритом. Чтобы обращение к гостям не казалось очень официальным, ведущий старается быть ближе к своим героям, говорить с ними на понятном, близком им языке. В результате получается очень насыщенная и приятная публике беседа. Ярким примером этого является выпуск, героиней которого была Ма Цзинфэн, рожденная в центральной провинции Хэнань, известная исполнительница Хэнаньской оперы, в ее речи нередко просачиваются слова из «хэнаньхуа» (хэнаньский язык).

Жизненная сцена Ма Цзиньфэн, 2009.4.22. 方话)

朱军：啥？！(河南地方话) 洛阳牡丹? 对不对（河南地

Чжу Цзюн: Что?! (хэнаньский диалект) Лоянский пион! Правильно или нет? (хэнаньский диалект)

马金风：这都是对我的高称吧！对我的鼓励！也谢谢大 家，谢谢谢谢! (均为河南地方话。观众掌声)

Ма Цзинфэн: Это высокое звание для меня! Чтобы поошрить меня! Спасибо всем! Спасибо! Cпасибо! (хэнаньский диалект) (Зрители аплодируют).

Учитывая данный пример, можно с увереностью сказать, что диалектизмы помогают отразить жизнь народа, передать «простонародный» колорит. В данном примере ведущий Чжу Цзюнь для того чтобы создать приятную беседу и расположить к себе гостя, часто использовал слова из хэнаньского диалекта. Именно из таких моделей речевого поведения китайцев и складывается языковая картина мира, определяющая его восприятие носителями китайских социально-этнических диалектов.

Наиболее частыми типами лексико-стилистических явлений на ток-шоу являются повторы (重复). Повторения дополняют речь эмоциональностью, выразительностью и стилизацией, и, кроме того, обычно служат важным средством связи между предложениями.

Чаще всего речь ведущего содержит лексические повторы (词汇的重复) видим, то есть повторения с явным назначением одной и той же формы слова в видимой части текста. Существительные повторяются особенно часто, например:

朱军: 嗯! 讨教一下，如果有很多人，还有一些人也有这 种遗感，你比如说我也有这种遗憾的话，我们应该用什么样的 方式，来弥补心里的这种缺憾呢? (《艺术人生: 范曾人文絮 语, 2009.3.18)

Чжу Цзюн: «Хм! Хочу спросить, есть ли люди, много ли людей, у кого тоже есть такое сожаление, у меня вот есть такое сожаление, мы должны найти способ пробудить это сожаление в душе?» («Человеческие докучливые разговоры Фан Цзэна», 2009.3.18)

Важной и распространенной чертой речи ведущего китайского ток-шоу является синтаксическое повтор (句 法重复). 
朱军: 哦，这让我从另外一个方面了解了，我们看上去都 很强健的女人，原来他们的心里呀这的有那么大一片非常柔弱 的地方，那我们接着往下说啊! 刚才开场的时候我就说了，你 们呢倆人还有一个共同的特点，都在用自己的努力或者用各自 的方式为传播中华传统文化有意无意地吧，因为了刚才你们那 个话，所以我只能加上有意无意地做着传播工作，那对你们而 言，你们觉得传统文化对当今的中国和当今的中国人意味着什 么?（《艺术人生》: 于单，上潮歌人生对话，2009.02.25)

Чжу Цзюн: «Вон оно что, это позволило нам увидеть другую сторону этой фразы: «Мы с виду сильные женщины» ... Оказывается, в сердце-то есть места для большой слабости... Ну, мы продолжим беседу! Только что, в начале, я говорил, у вас обеих есть общее, каждая использовала свои силы или собственный способ, то ли специально, то ли нет, чтобы распространять китайскую традиционную культуру. Так как вы только что сказали эти слова, я могу только добавить: «то ли специально, то ли нет» вы осуществляете просветительскую работу. Тогда, как вы думаете, что означает традиционная культура для сегодняшнего Китая и сегодняшних китайцев?» («Разговор о жизни с Ю Шан и Ван Чаогэ», 2009.02.25).

Речь Чжу Цзюня содержит не только пословицы, но и короткие и устойчивые высказывания в повседневном дискурсе - поговорки, часто назидательные по своей природе, образно определяющие любое явление жизни главным образом с точки зрения его эмоционально выразительной оценки.

朱军: 咱们经常说这样一句俗话《心明才能眼亮》，他们 眼晴虽然看不见，但是呢，我们看到了他们非常明亮健康的心 灵，这就足够了! (《艺术人生》: 音乐光明行，2008.9.24)

Чжу Цзюн: «Мы часто вспоминаем такую пословицу «Со светлым сердчем и глаза видят зорче». Их глаза хотя не видят, однако, мы - увидели их очень светлые сердца, этого достаточно! («Свет музыки», 2008.9.24).

朱军: 哎吸呀! 看了这个短片真是让人感概万千! 《人已走 远，音容宛在》呀! 真的! 有那么多那么多的画面，下子在脑 海当中浮现出来了。（<艺术人生>：追忆赵丽蓉，2008.12.25

Чжу Цзюн: «Эх! Посмотрев этот отрывок, охватило горестное раздумье! «Человек ушел, а голос и облик остались»! Правда! Есть так много, так много картин. Разом всплыли в голове». («Вспоминая Чжао Лижун», 2008.12.25). Кроме поговорки, в этом примере наблюдаются повтор и образное выражение метафорического типа.

Очень часто ведущий использует такой оборот речи как сравнения.

朱军: 而姐姐的发型就更加地具有特色，要我说象一个拖 把，技着象床单一样的衣服，当然这都是玩笑!（<艺术人 生: 齐豫2008.04.24)

«А прическа сестры еще более особенна, я бы сказал, похожа на швабру, и одежда - как накинутая простынь. Конечно же, это шутка!» («Ци Юй», 2008.04.24).

Проведенный анализ позволил нам охарактеризовать речь Чжу Цзюня с точки зрения фонетики как правильную, с высоким уровнем владения путунхуа. Чжу Цзюнь представляется нам спокойным, серьезным и уравновешенным человеком. Произношение слов ясное, сильное, звучное. Темп речи достаточно умеренный.

На лексико-стилистическом уровне в выступлении ведущего ток-шоу «Жизнь как искусство» следует отметить такие положительные характеристики, как отсутствие сленга и заимствованных иностранных слов, использование диалектной лексики в разговоре с героями. Чтобы обращение с гостями не казалось слишком официальным, ведущий стремится сблизиться со своими героями, разговаривать с ними на понятном и знакомом языке. Стилистическими доминантами речи Чжу Цзюня являются модальность, выразительность, непринужденность разговора. Речь богата лексико-стилистическими явлениями, такие как лексические повторы и синтаксические повторы. Повторение фраз необходимо для привлечения внимания коммуникаторов к смыслу высказывания и теме обсуждения. С точки зрения фразеологической стилистики в его речи встречаются фразеологические сочетания: идиомы, пословицы и поговорки, а также метафоры. Фразеологизмы помогают лучше понять историю и характер китайского народа, а также способствуют развитию языка и повышают уровень культуры.

В целом речевое поведение ведущего характеризуется прекрасными интонационно-дикторскими данными, оно выразительно, с чувством формы.

\section{ЛИТЕРАТУРА}

1. Акинфиев С.Н. Жанровая структура российского развлекательного телевидения - М.: Просвещение, 2008. - 217 с.

2. Комиссаров В.Н. Общая теория перевода. Учебное пособие. - М.: ЧеРо, 1999. - 136 с.

3. Ростоцкая Е.Б. Функциональная специфика личностной оценки в коммуникации ток-шоу (на материале немецкого языка): дис. ... канд. филол. наук. Барнаул, 2002. -179 c

4. Скотт Дж.Г. Ток-шоу: Могущество и влияние разговорных передач на радио и телевидении; пер. с англ. Мяо Ди. — Пекин, 1999. - 249 с. 